\title{
Is there any Effect of Core Exercises on Anaerobic Capacity in Female Basketball Players?
}

\author{
Recep Soslu ${ }^{1}$, Ömer Özer ${ }^{1}$, Melek Güler ${ }^{1}$, Ali Ahmet Doğan ${ }^{2}$ \\ ${ }^{1}$ Karamanoğlu Mehmetbey University, Physical Education and Sport, Karaman, Turkey \\ ${ }^{2}$ Kırıkkale University, Faculity of Physical Education and Sport Science, Kırıkkale, Turkey \\ Correspondence: Recep Soslu, Karamanoğlu Mehmetbey University, Physical Education and Sport, Karaman, Turkey
}

Received: January 9, 2019

doi:10.11114/jets.v7i3.3959
Online Published: February 13, 2019

URL: https://doi.org/10.11114/jets.v7i3.3959

\begin{abstract}
This study was planned in order to determine the effect of core exercises on anaerobic capacity of female basketball players. Twelve female athletes who play basketball participated in the study voluntarily. The athletes had 3 sets of repetitive core exercise program performed 4 days a week for 8 weeks at the end of their basketball trainings. The height of the athletes was $165 \pm 6.57 \mathrm{~cm}$, body weight was $58.73 \pm 7.42 \mathrm{~kg}$, age was $19.75 \pm 1.05$, and athletic age was $6.11 \pm 2.11$. According to the analysis of the results, peak power, average power, right and left hand grip strengths and right and left arm fat percentages of post-tests were found to have a statistically significant difference than the pre-tests ( $\mathrm{p}<0.05)$. To sum up, there are very few studies on the anaerobic capacity of female basketball players, especially on the upper extremities. It is observed that basketball players have a stronger anaerobic capacity in attack and defense and that core exercises have a positive effect on certain basketball-specific technical skills such as passing, shooting, dribbling and defensive movements, and in this sense, they will also increase the performance of the athletes.
\end{abstract}

Keywords: core, Wingate, anaerobic, force, basketball

\section{Introduction}

The work capacity of the skeletal muscles generated using anaerobic energy transfer systems during maximal and supra-maximal physical activity is defined as "anaerobic capacity" and the value of this work in unit time is expressed as "anaerobic power" ( $\mathrm{kgm} / \mathrm{sc}, \mathrm{kgm} / \mathrm{min}$, watt), (Y1ldı, 2012). Anaerobic performance is a term that is of great importance for sports branches that are completed in a short time or that require explosive force (Erkılıç, 2015). In other words, this increase in anaerobic performance is the increase resulted in the efficiency of the ATP-PC storage and the lactic acid system. The athlete's ability to use energy resources is an important factor for sportive performance (Özkan et al. 2011). Anaerobic performance, gender and muscle mass are all related to each other and an important factor in determining the anaerobic performance (Thomas et al. 2009). Anaerobic capacity in women reaches maximum level between the ages of 20 and 25, but decreases due to environmental (living habits, activity level) factors and hereditary factors (Jordan et al. 1997). Since the anaerobic requirements are predominant and repetitive during a match, it is stated that basketball is often more dependent on anaerobic capacity than aerobic capacity and that anaerobic glycolysis as a source of energy is significantly involved in the performance of various high intensity activities (Halder et al. 2016).

The main objective of basketball is to achieve the highest sportive performance. In addition to individual talents and technical skills, athletes with a high level of physical and physiological competence are needed to achieve superior performance (Aksen-Cengizhan et al. 2017). It is stated that the physical structure, technical, tactical and mental abilities that are important for the basketball branch are prominent and it is important to improve the physical fitness for optimal performance (Bakırcı \& Kılınç, 2014).This is a process that demands more strain. A good core workout will enable athletes to be more strained and also the technical movements are more efficiently and better exhibited (Egesoy et al. 2018). The core is defined as the whole muscle system causing the spine to get its most effective state and its protection supported by the abdominal and spinal muscles during a movement that has functions in the body's active movements (Gür \& Ersöz, 2017). Increasing muscle strength and reducing the percentage of body fat lay an important role in the fulfillment of many functions such as the connection between the upper and lower parts of the body during a movement, transfer of energy, supporting the weight reflected on the body, the spine and the protection of nerve roots etc. (Shirey et al 2012). Although there are many studies in the literature, there are not many studies investigating the 
effects of core exercises on anaerobic capacity of upper extremity. Therefore, it was planned to determine the effect of core exercises applied to women basketball players on anaerobic capacity.

\section{Materials and Methods}

Study group consisted of 12 female athletes who play basketball actively and participated in the study voluntarily. The athletes were informed about the duration of the study. The height of the athletes was $165 \pm 6.57 \mathrm{~cm}$, body weight was $58.73 \pm 7.42 \mathrm{~kg}$, age was $19.75 \pm 1.05$, and athletic age was $6.11 \pm 2.11$.

\subsection{Anthropometric Measurements}

The height of the athletes participating in the study was measured by a stadiometer (Holtain, UK) with a precision of \pm $0.01 \mathrm{~mm}$, and body weight was measured with an electronic scale (Tanita BC $418 \mathrm{~A}$, Japan) with a precision of $\pm 0.1 \mathrm{~kg}$. Body analysis was performed with the device called Tanita BC 418 A. Bio Impedance Analysis $50 \mathrm{kHz}$ electrical current was sent to 5 separate zones. The fat percentage of the arms, legs and the body was analyzed as fat-free mass and muscle weight (Soslu et al. 2017)

\subsection{Study Design}

The athletes participated in the study were provided 3 sets of repetitive core exercise programs (Table 1) to be performed 4 days a week for 8 weeks at the end of their basketball trainings(Dilber at al. 2016).

Table 1. Core training program (Dilber at al. 2016)

\begin{tabular}{lccc}
\hline Core exercises & Set $\mathbf{1}$ & Set 2 & Set 3 \\
\hline Side Bend & $30 \mathrm{sec}$ & $30 \mathrm{sec}$ & $30 \mathrm{sec}$ \\
Power Shiver & $30 \mathrm{sec}$ & $30 \mathrm{sec}$ & $30 \mathrm{sec}$ \\
Alternate Legs Jump & $30 \mathrm{sec}$ & $30 \mathrm{sec}$ & $30 \mathrm{sec}$ \\
Side Bridge & $30 \mathrm{sec}$ & $30 \mathrm{sec}$ & $30 \mathrm{sec}$ \\
Abdominal Plank & $30 \mathrm{sec}$ & $30 \mathrm{sec}$ & $30 \mathrm{sec}$ \\
Alternate Plank & $30 \mathrm{sec}$ & $30 \mathrm{sec}$ & $30 \mathrm{sec}$ \\
Squat & 20 & 20 & 20 \\
V-Up & 20 & 20 & 20 \\
Crunch & 20 & 20 & 20 \\
Lying Twist Trunk & 20 & 20 & 20 \\
Alternate Superman & 20 & 20 & 20 \\
\hline
\end{tabular}

Taking into account the mobilization and stabilization of the core exercises, 1-week adaptation training was provided for the athletes before the application for accurate performance of the exercises and to correct the errors. At the end of the adaptation training, the body analysis, anaerobic capacity and arm strength of the athletes were recorded according to the test protocol and they were analyzed once more at the end of the 8th week (Figure 1).

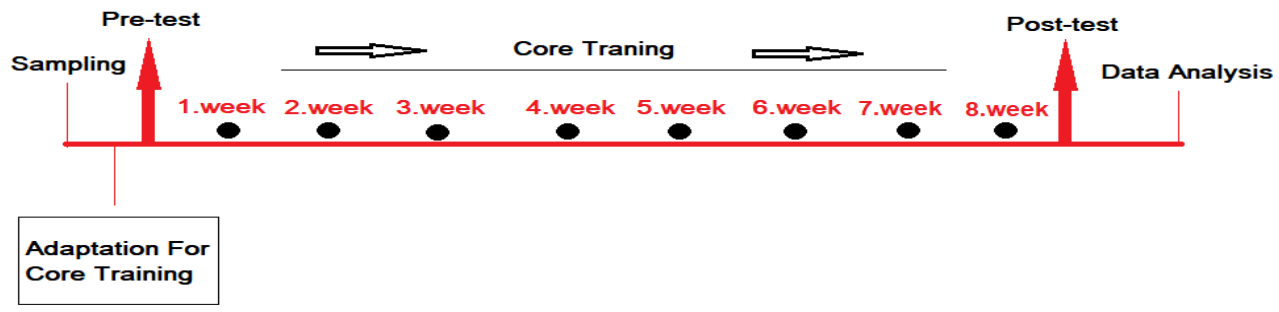

Figure 1. Study design

\subsection{Wingate Anaerobic Power Test}

The Wingate anaerobic power test (WAnT) was performed on Monark $891 \mathrm{E}$ (Sweden) arm ergometer, which was connected to a computer modified for the arm and operating with a compatible software. Athletes are provided detailed information about the test prior to the test and then a 4-5 minutes of warming protocol is carried out on a cycle ergometer with 60-70 W workload, 60-70 RPM pedal speed, including 2 or 3 sprints of 4-8 seconds. After warming, 3-5 minutes of passive rest was given. Seat and handlebar settings were done for each subject after warm-up and rest. For 
each athlete, $30 \mathrm{~g}$ load per $\mathrm{kg}$ was applied as external resistance during the test and the test was started after the arm was placed on the scale of the ergometer. The athletes were asked to reach the highest pedal speed as soon as possible without resistance. Subjects pedaled to the highest speed with their arms for 30 seconds against external resistance. Athletes were encouraged verbally throughout the test. Information on the power parameters during the test was recorded at $1000 \mathrm{~Hz}$ and transferred to the software program (Özkan et al. 2011).

\subsection{Handgrip Strength}

Handgrip strength of the athletes was measured with Takei Grip-D brand hand dynamometer. After five minutes of warm-up, the subject was asked to squeeze the dynamometer while standing in an upright position, without bending the arm and touching the body with the arm at an angle of $45^{\circ}$. The foregoing was repeated three times for the right and left hands and the highest value was recorded (Özer \& Kılınç 2012).

\subsection{Analysis of the Data}

Mean \pm standard deviation of the data was calculated. Normal distribution and homogeneity of the parameters were checked with Shapiro-Wilk, and Levene's test. The differences between after and before results in both Pre and post-test groups were analysed by factorial ANOVA with repeated measures. The probability level for significance was set at $\mathrm{p}<0.05$. An analysis was performed using SPSS version 23.0(Chicago, IL, USA).

\section{Findings}

Table 2. Basketball Players' Right-Left Arm Fat Percentage values from Pre and Post-Tests

\begin{tabular}{|c|c|c|c|c|}
\hline Variables & Groups & $\mathbf{N}$ & Mean & $\mathbf{P}$ \\
\hline Right Arm Fat Percentage & Pre-Test & \multirow{8}{*}{12} & $28.57 \pm 2.74$ & \multirow{2}{*}{0,011} \\
\hline$(\%)$ & Post-Test & & $19.31 \pm 1.73^{\pi}$ & \\
\hline Left Arm Fat Percentage & Pre-Test & & $28.83 \pm 2.75$ & \multirow{2}{*}{0,015} \\
\hline$(\%)$ & Post-Test & & $19.63 \pm 2.01^{\pi}$ & \\
\hline Right Arm Muscle & Pre-Test & & $1.95 \pm .90$ & \multirow{2}{*}{0,124} \\
\hline (kg) & Post-Test & & $2.22 \pm .14$ & \\
\hline Left Arm Muscle & Pre-Test & & $1.94 \pm .09$ & \multirow{2}{*}{0,181} \\
\hline$(\mathbf{k g})$ & Post-Test & & $2.17 \pm .13$ & \\
\hline
\end{tabular}

$\pi: p \overline{<0,05}$

According to Table 2, the average fat percentage of the right arm was determined in the pre-test $(28.57 \pm 2.74)$, and the average fat in the right arm was determined as $(19.31 \pm 1.73)$ in the post-test. There is a statistically significant difference in right arm percentage fat pre-test and post-test results. The average fat percentage of the left arm was determined in the pre-test $(28.83 \pm 2.75)$, and the average fat in the left arm was determined as $(19.63 \pm 2.01)$ in the post-test. There is a statistically significant difference in left arm percentage fat pre-test and post-test results. The average of the right arm

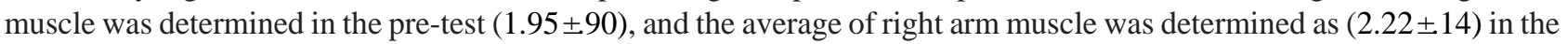
post-test. The average of the left arm muscle was determined in the pre-test (1.94 \pm .09$)$, and the average of left arm muscle was determined as $(2.17 \pm .13)$ in the post-test.

Table 3. Basketball Players' Right-Left Handgrip Strength values from Pre and Post-Tests

\begin{tabular}{ccccc}
\hline Variables & Groups & N & Mean & P \\
\hline Strength Right Handgrip & Pre-Test & & $26.90 \pm 1.58$ & .041 \\
$(\mathbf{k g})$ & Post-Test & \multirow{2}{*}{12} & $29.15 \pm 1.70^{\pi}$ & \\
Strength Left Handgrip & Pre-Test & & $25.95 \pm 1.60$ & .043 \\
$(\mathbf{k g})$ & Post-Test & & $28.18 \pm 1.18^{\pi}$ & \\
\hline
\end{tabular}

$\pi: \overline{p<0,05}$

According to Table 3, the average of the strength right handgrip was determined in the pre-test $(26.90 \pm 1.58)$, and the average strength right handgrip was determined as $(29.15 \pm 1.70)$ in the post-test. There is a statistically significant difference in strength right handgrip pre-test and post-test results. The average of the strength left handgrip was determined in the pre-test $(25.95 \pm 1.60)$, and the average strength left handgrip was determined as $(28.18 \pm 1.18)$ in the post-test. There is a statistically significant difference in strength left handgrip pre-test and post-test results. 
Table 4. Basketball Players' Anaerobic Power Capacity values from Pre and Post-Tests

\begin{tabular}{clccc}
\hline Variables & Groups & N & Mean & P \\
\hline \multirow{2}{*}{$\mathbf{P}(\mathbf{W})$} & Pre-Test & & $185.11 \pm 20.39$ & .033 \\
& Post-Test & & $241.46 \pm 18.08^{\pi}$ & \\
$\mathbf{T}(\mathbf{W})$ & Pre-Test & 12 & $203.93 \pm .87$ & .786 \\
& Post-Test & & $195.53 \pm 14.59$ & \\
$\mathbf{A}(\mathbf{W})$ & Pre-Test & Post-Test & $113.55 \pm 8.02$ & .046 \\
& & $134.73 \pm 5.79^{\pi}$ & \\
\hline
\end{tabular}

: $p<0,05$ P (Peak Power),T (Time At Peak Power), A (Average Power),W(Watt).

According to Table 4, the average of the peak power was determined in the pre-test (185.11 \pm 20.39$)$, and the average of peak power was determined as $(241.46 \pm 18.08)$ in the post-test. There is a statistically significant difference in peak power pre-test and post-test results. The average of the time at peak power was determined in the pre-test (203.93 \pm .87$)$, and the average of time at peak power was determined as $(241.46 \pm 18.08)$ in the post-test. The average of average power was determined in the pre-test (113.55 \pm 8.02$)$, and the average of average power was determined as $(134.73 \pm 5.79)$ in the post-test. There is a statistically significant difference in average power pre-test and post-test results.

\section{Conclusion}

There are limited studies on upper extremity of the core training and they have conflicting and overlapping aspects when compared to our results. Exercise models with high threshold values, such as core training, are used as an effective tool for improving performance and fixing the balance of energy. During high intensity trainings with high threshold values, fats hydrolyze and provide energy and as a result, a decrease in body fat and an increase in muscle density will be expected. Differences in performance with the body's lean mass are somewhat affected by the proportion of body fat.

In our study, when the pre- and post-test arm fat percentages of the basketball players were examined, it is seen that the post-test arm fat percentages of the athletes decreased compared to the pre-test arm fat percentages. It is stated that core training did not affect body mass index (Dilber at al. 2016), lean body mass, other body composition parameters and body weight (Dilber at al. 2016; Segal et al. 2004; Dedecan, 2016; Barak et al. 2016) but the percentage of body fat was effected positively (Dedecan, 2016; Prabhakaran et al. 1999; Arslan et al. 2009). It is indicated that the increase in body fat weight affects the ability to maintain the core stability and increase the weight load in the core muscles, and that this will have a more negative effect on the core muscle function than body weight (King et al. 2012). Body weight is very important in basketball, especially because it is linked to strength. Body weight is an important factor affecting the energy expenditure in the exercises. The increase in body weight with regards to basketball players will have a negative effect on their pass and shoot performances and their energy consumption will become higher as well. Therefore, the difference between the oxygen utilization capacities of the athletes with higher body weight will be significant. In our study, it is thought that core exercises have a positive effect on body weight.

When the arm strengths of the basketball players were examined, it was determined that the average of the post-test grip strength was higher than the pre-test grip strength average. In basketball, the muscles of the arms and legs are expected to be strong, and the workout of the abdominal muscles is also important. Technical movements such as a good handling of the ball, passing, dribbling, and shooting, largely depends on the strength of the arms, wrists and, in particular, the fingers. In the shootings of male and female athletes; when the kinematics of the shoot is examined, it is noted that men use their elbows to increase the speed of the ball while women use both their shoulders and elbows. In the studies carried out, it is stated that the core exercises have effects on the strengths of lower extremity (Marshall\& Murphy, 2005; Cosio-Lima et al. 2003; Drinkwater et al. 2007; Myer et al. 2006), and the body and back muscles (Carpes et al. 2008; Granacher et al. 2013; Sukalinggam et al. 2012; Cowley et al. 2007). In basketball, basketball-specific technical skills such as pass, shoot, dribbling and defensive movements and motor characteristics are important facts for performance. There was a significant increase in maximum throw speed (Saeterbakken et al. 2011), in health ball throw strength from the chest (Sharrock et al. 2011) and in lumbar cervical spine upper extremity functions (Özer, 2009), and in right-left handgrip strength (Dilber at al. 2016), and also in 1 min. push-ups and shuttle measurements (Dedecan, 2016). Core exercises lead to positive structural change in muscles, while strengthening neural adaptation at the same time (Iacono et al. 2014). This positive effect is thought to be related to the increasing intensity of the movements based on the upper extremity in basketball.

In our study, pre-post test anaerobic power capacities of basketball players were examined; the following results were 
found out: the post-test peak power averages increased compared to the pre-test average. Time at peak power post-test averages were decreased compared to pre-test time at peak power averages. Average power post-test averages increased compared to pre-test averages. Due to the intensive flow and continuity of the basketball game, it is very important to develop both aerobic and anaerobic endurance. Because energy production in both offense and defense systems in basketball has an important role (K1lınç et al. 2011). Fatigue can adversely affect the attack and defense performance in a certain part of the game in basketball (Soslu et al. 2017). Minimizing the negative effects of fatigue occurring in athletes is very important in terms of performance. When the studies carried out were examined, it was observed that the strength workouts increase the upper extremity anaerobic capacity (Soslu et al. 2017; Özdil, 2016; Colado et al. 2010; Ivoilov et al. 1981). It is stated that high anaerobic capacity affects the level of success positively in terms of shooting, pass and dribbling techniques in basketball (Uygur et al. 2010).

To sum up, there are very few studies on the anaerobic capacity of female basketball players, especially on the upper extremities. It is observed that basketball players have a stronger anaerobic capacity in attack and defense and that core exercises have a positive effect on certain basketball-specific technical skills such as passing, shooting, dribbling and defensive movements, and in this sense, they will also increase the performance of the athletes.

\section{References}

Aksen-Cengizhan, P., Gülü, M., Erikoğlu-Örer, G., \& Doğan, A. A. (2017). Basketbolda farklı gruplama yöntemleriyle oynanan dar alan oyunlarının egzersiz şiddetlerinin karşılaştııılması. Celal Bayar University Journal of Physical Education and Sport Sciences, 12(2), 145-154.

Arslan, E., Yılmaz, İ., \& Aras, Ö. (2009). Elit kadın basketbol oyuncularında ve düzenli spor yapan kadınlarda vücut kompozisyonu ve esneklik ilişkisi: pilot çalışma. Turkish Journal of Physiotherapy and Rehabilitation, 20(2), 83-88.

Bakırcı, A., \& Kılınç, F. (2014). Hazırlık periyodunda uygulanan kombine antrenmanların üniversite basketbol takımının performans düzeyine etkisi. Inonu University, Journal of Physical Education and Sport Sciences, 1(2), 48-67.

Barak, R., Özkan, A., \& Öz, Ü. (2016). Comparison of some performance variables of lower and upper body in sub-elite female basketball and handball players. International Journal of Science Culture and Sport, 4(3), 882-889. https://doi.org/10.14486/IntJSCS638

Carpes, F. P., Reinehr, F. B., \& Mota, C. B. (2008). Effects of a program for trunk strength and stability on pain, low back and pelvis kinematics, and body balance: apilot study. Journal of Bodywork and Movement Therapies, 12(1), 22-30. https://doi.org/10.1016/j.jbmt.2007.05.001

Colado, J. C., García-Massó, X., Pellicer Catalán, M., Alakhdar, Y., Benavent, J., \& Cabeza Ruiz, R. (2010). A comparison of elastic tubing and isotop resistance exercises. International Journal of Sports Medicine, 31(11), 810-817. https://doi.org/10.1055/s-0030-1262808

Cosio-Lima, L. M., Reynolds, K. L., Winter, C., Paolone, V., \& Jones, M. T. (2003). Effects of physioball and conventional floor exercises on early phase adaptations in back and abdominal core stability and balance in women. The Journal of Strength \& Conditioning Research, 17(4), 721-725.

Cowley, P. M., Swensen, T., \& Sforzo, G. A. (2007). Efficacy of instability resistance training. International Journal of Sports Medicine, 28(10), 829-835. https://doi.org/10.1055/s-2007-964893

Dedecan, H. (2016). Adolesan dönem erkek öğrencilerde core antrenmanlarının bazı fiziksel ve fizyolojik özellikleri üzerine etkisi (Doktora tezi, Selçuk Üniversitesi Sağlık Bilimleri Enstitüsü).

Dilber, A. O., Lağap, B., Akyüz, Ö., Çoban, C., Akyüz, M., Taş., M., \& Özkan, A. (2016). Erkek futbolcularda 8 haftalık kor antrenmanının performansla ilgili fiziksel uygunluk değişkenleri üzerine etkisi. Celal Bayar University Journal of Physical Education and Sport Sciences, 11(2), 77-82.

Drinkwater, E. J., Pritchett, E. J., \& Behm, D. G. (2007). Effect of instability and resistance on unintentional squat-lifting kinetics. International Journal of Sports Physiology and Performance, 2(4), 400-413. https://doi.org/10.1123/ijspp.2.4.400

Egesoy, H., Alptekin, A., \& Yapıc1, A. (2018). Sporda kor egzersizler. International Journal of Contemporary Educational Studies, 4(1), 10-21.

Erk1lı̧, A. O. (2015). Beden ĕgitimi ve spor yüksekokulunda ĕgitim gören genç erkek sporcularda morfolojik değişkenler ile üst ekstremiteden elde edilen anaerobik değerler arasındaki ilişkinin incelenmesi (Yüksek lisans tezi, Bartın Üniversitesi, Eğitim Bilimleri Enstitüsü). 
Granacher, U., Lacroix, A., Muehlbauer, T., Roettger, K., \& Gollhofer, A. (2013). Effects of core instability strength training on trunk muscle strength, spinal mobility, dynamic balance and functional mobility in older adults. Gerontology, 59(2), 105-113. https://doi.org/10.1159/000343152

Gür, F., \& Ersöz, G. (2017). Evaluatıon of the effects of core traınıng on the core strength, statıc and dynamıc balance characteristics of tennis athletes in the 8-14 age group. Spormetre Journal of Physical Education and Sport Sclences, 15(3), 129-138.

Halder, K., Pathak, A., Os, T., \& Chatterjee, M. S. A. (2016). Physical and physiological comparison between indian female college basketball players and sedentary students. Advances in Applied Physiology, 1(2), 18-23. https://doi.org/10.11648/j.aap.20160102.11

Iacono, A. D., Martone, D., Alfieri, A., Ayalon, M., \& Buono, P. (2014). Core stability training program (cstp) effects on static and dynamic balance abilities. Gazzetta Medica Italiana Archivio Per Le Scienze Mediche, 173(4), 197-206.

Ivoilov, A. V., Smirnov, Y. G., Chikalov, V. V., \& Garkavenko, A. G. (1981). Effects of progressive fatigue on shooting accuracy. The Theory and Practice of Physical Training Culture, 7, 12-14.

Jordan, P. A., Thomson, A. J., Ralph, E. T., Guest, J. R., \& Green, J. (1997). Fnr is a direct oxygen sensor having a biphasic response curve. Febs Letters, 416(3), 349-352. https://doi.org/10.1016/S0014-5793(97)01219-2

Kılınç, F., Erol, A. E., \& Kumartaşl1, M. (2011). Basketbol alt yapıda uygulanan kombine teknik antrenmanlarının bazı fiziksel, kuvvet ve teknik özellikler üzerine etkisi. International Journal of Human Sciences, 8(1), 213-230.

King, A. C., Challis, J. H., Bartok, C., Costigan, F. A., \& Newell, K. M. (2012). Obesity, mechanical and strength relationships to postural control in adolescence. Gait \& Posture, 35(2), 261-265. https://doi.org/10.1016/j.gaitpost.2011.09.017

Marshall, P. W., \& Murphy, B. A. (2005). Core stability exercises on and off a swiss ball. Archives of Physical Medicine and Rehabilitation, 86(2), 242-249. https://doi.org/10.1016/j.apmr.2004.05.004

Myer, G. D., Ford, K. R., Brent, J. L., \& Hewett, T. E. (2006). The effects of plyometric vs. dynamic stabilization and balance training on power, balance, and landing force in female athletes. Journal of Strength and Conditioning Research, 20(2), 345. https://doi.org/10.1519/R-17955.1

Özdil, G. (2016). Boksörlerde kuvvet antrenmanlarının maksimal kuvvet ve anaerobik güce etkisi (Doktora tezi, Selçuk Üniversitesi Sağlık Bilimleri Enstitüsü).

Özer, D. (2009). Farklı kolumna vertebralis bölgelerindeki stabilizasyon eğitimlerinin üst ve alt ekstremite fonksiyonlarına ve dengeye etkileri. Yayımlanmamıș Doktora Tezi, Hacettepe Üniversitesi, Spor Fizyoterapistliği Programi, Ankara.

Özer, Ö., \& Kılınç, F. (2012). Elite athletes in individual and team strength, speed and flexibility to compare their performance. Journal of Human Sciences, 9(1), 360-371.

Özkan, A., Koz, M., \& Ersöz, G. (2011). Wingate anaerobik güç testinde optimal yükün belirlenmesi. Spormetre Journal of Physical Education and Sport Sclences, 9(1), 2-3.

Prabhakaran, B., Dowling, E. A., Branch, J. D., Swain, D. P., \& Leutholtz, B. C. (1999). Effect of 14 weeks of resistance training on lipid profile and body fat percentage in premenopausal women. British Journal of Sports Medicine, 33(3), 190-195. https://doi.org/10.1136/bjsm.33.3.190

Saeterbakken, A. H., Van Den Tillaar, R., \& Seiler, S. (2011). Effect of core stability training on throwing velocity in female handball players. The Journal of Strength \& Conditioning Research,25(3), 712-718. https://doi.org/10.1519/JSC.0b013e3181cc227e

Segal, N. A., Hein, J., \& Basford, J. R. (2004). The effects of pilates training on flexibility and body composition: an observational study1. Archives of Physical Medicine and Rehabilitation, 85(12), 1977-1981. https://doi.org/10.1016/j.apmr.2004.01.036

Sharrock, C., Cropper, J., Mostad, J., Johnson, M., \& Malone, T. (2011). A pilot study of core stability and athletic performance: is there a relationship?. International Journal of Sports Physical Therapy, 6(2), 63.

Shirey, M., Hurlbutt, M., Johansen, N., King, G. W., Wilkinson, S. G., \& Hoover, D. L. (2012). The İnfluence of core musculature engagement on hip and knee kinematics in women during a single leg squat. International Journal of Sports Physical Therapy, 7(1), 1.

Soslu, R., Eyüboğlu, E., Çuvalcioğlu, İ. C., \& Özkan, A. (2017). Effects of blood parameters and some morphological variables on some upper extremity physical fitness performance in female basketball players. International Journal 
of Cultural and Social Studies (Uksad), 3(Special Issue 2), 347-353.

Sukalinggam, C., Sukalinggam, G., Kasim, F., \& Yusof, A. (2012). Stability ball training on lower back strength has greater effect in untrained female compared to male. Journal of Human Kinetics,33, 133-141. https://doi.org/10.2478/v10078-012-0052-2

Thomas, K., French, D., \& Hayes, P. R. (2009). The effect of two plyometric training techniques on muscular power and agility in youth soccer players. The Journal of Strength \& Conditioning Research, 23(1), 332-335. https://doi.org/10.1519/JSC.0b013e318183a01a

Uygur, M., Goktepe, A., Ak, E., Karabörk, H., \& Korkusuz, F. (2010). The effect of fatigue on the kinematics of free throw shooting in basketball. Journal of Human Kinetics, 24, 51-56. https://doi.org/10.2478/v10078-010-0019-0

Yıldız, S. A. (2012). Aerobik ve anaerobik kapasitenin anlamı nedir. Eurasian Journal of Pulmonology, 14(1), 1-8.

\section{Copyrights}

Copyright for this article is retained by the author(s), with first publication rights granted to the journal.

This is an open-access article distributed under the terms and conditions of the Creative Commons Attribution license which permits unrestricted use, distribution, and reproduction in any medium, provided the original work is properly cited. 